\title{
The Bank Lending Channel of Monetary Policy? The Panel Evidence from Egypt ${ }^{*}$
}

\author{
Mohamed AseelShokr, Zulkefly AbdulKarim, ${ }^{\text {ab }}$ Mansor Jusoh, and \\ Mohd. Azlan Shah Zaidi ${ }^{\text {}}$ \\ ${ }^{a}$ Faculty of Economics and Management, Universiti Kebangsaan Malaysia (UKM), Malaysia \\ ${ }^{b}$ Faculty of Commerce, Tanta University, Egypt
}

\begin{abstract}
This paper examines the relevance of the bank lending channel of monetary policy in Egypt using bank-level data. Previous empirical studies in Egypt that used macro-level data have not supported the relevance of the bank lending channel. However, using a sample of 32 commercial banks for the period from 1998 until 2011 and a dynamic panel GMM technique, the empirical findings revealed the relevance of the bank lending channel of monetary policy in Egypt. Moreover, there is a heterogeneity effect of monetary policy on bank loans according to bank size, in which the small banks are more affected during a monetary contraction than larger banks. This finding signals that the monetary authorities in Egypt should take cognizance of the stability of interest rates in order to stabilize the bank loan supply.
\end{abstract}

Abstrak: Makalah ini membahas relevansi bank penyalur pinjaman kebijakan moneter/bank sentral di Mesir dengan menggunakan data bank bertingkat. Beberapa studi empiris sebelumnya yang menggunakan data tingkat makro belum mendukung relevansi penyaluran pinjaman bank. Namun, dengan menggunakan sampel dari 32 bank umum dari periode 1998 hingga 2011 dan dengan memakai teknik panel GMM dinamis, kami menemukan bukti empiris yang menunjukkan adanya relevansi saluran peminjaman bank kebijakan moneter di Mesir. Selain itu, ada efek heterogenitas kebijakan moneter pinjaman bank sesuai dengan ukuran bank, di mana pada umumnya bank yang kecil lebih terpengaruh selama kontraksi moneter dibandingkan dengan bank yang lebih besar. Temuan ini menunjukan bahwa pihak otoritas moneter di Mesir harus bertanggung jawab atas kestabilan suku bunga agar terjaga kestabilan pasokan pinjaman bank.

Keywords: bank lending channel; generalized method of moments (GMM); monetary policy

JEL Codes: C100; E50; E52

*) This paper is a part of dissertation at Faculty of Economics and Management, Universiti Kebangsaan Malaysia.

* Corresponding author's e-mail: m_aseel1975@yahoo.com

ISSN: $1141-1128$

http://journal.ugm.ac.id/gamaijb 


\section{Introduction}

The central banks change their interest rate policy, as an intermediate target of the monetary policy, to achieve the ultimate targets of their monetary policy, namely low inflation, full employment, equilibrium in the balance of payments and sustainability of the long term economic growth. However, the effects of interest rates on macroeconomic variables are often indirect, and do not manifest themselves immediately. This is because any changes in interest rate policy will influence the macroeconomic variables through several monetary policy channels, such as the credit channel (balance sheet and bank lending channel), exchange rate channel, equity price channel, and asset prices channel. For example, an expansionary monetary policy through a decrease in interest rates, will raise the bank reserves, increase the bank loans, and subsequently will have an important impact on investment and consumption, as well as output. This indicates the importance of the bank lending channel in transmitting monetary policy shocks to the real sector activity. In Egypt's experience, the banking sector plays an important role in the domestic economy by providing funds to the private sector. For example, the percentage of domestic credit to the private sector, as a percentage of gross domestic product is considered to be large, at 31.1 percent in 2011, 29.1 percent in 2012, and 27.8 percent in 2013 (World Bank). Therefore, given the important role of bank credit, it is expected that the bank lending channel has relevance in Egypt's case.

The bank lending channel analyzes the effects of monetary policy on banks' balance sheets to influence the loan supply. An increase in interest rates, as a monetary policy variable, reduces banks' reserves, and thus loans and thereby affects the spending capacity of borrowers (Bernanke 1992). In the bank lending channel, monetary policy impacts loans through traditional interest rates and external finance premiums ${ }^{1}$. This is because monetary policy changes the interest rate levels and the size of the external finance premium. Changes in traditional interest rates and external finance premiums have a stronger effect on bank loans than just changes in the interest rate (Bernanke and Gertler 1995). The bank lending channel, as a part of the credit channel, is premised on the fact that information is asymmetric, banks are heterogeneous and banks occupy an important role in the financial system. However, large banks are capable of solving the asymmetric information problem in the capital market (Mishkin 1996).

There are five arguments relating to the external finance premium in the credit market. Firstly, the imperfect information changes the wedge of costs between internal and external funds, which amplifies the effect of monetary policy shocks on loans. The imperfect information between small and large banks causes the heterogeneity effect of monetary policy because large banks have more information than small banks. Secondly, the agency cost affects the wedge of costs between internal and external funds. Small banks are subject to higher agency costs than larger banks, which leads to the differences in behavior between the small and large banks. Thirdly, the lenders' expected cost of the contracts also affects the external finance premium, such as evaluation, monitoring and

\footnotetext{
${ }^{1}$ The external finance premium is the difference in cost between funds raised externally (by issuing equity and debt) and funds generated internally (by retaining earnings).
} 
collection of the contracts. Fourthly, the cost of distortions in borrower's behavior, such as collateral requirements, affects the external finance premium between small and large banks. Finally, the bank financial position impacts the external finance premium. The greater the bank's financial position is, the lower the external finance premium should be. Since large banks have better a financial position than small banks, small banks are more sensitive to monetary policy shocks than large banks (Bernanke and Gertler 1995; Walsh 2003). ${ }^{2}$

Many changes in the banking sector were affected during the reform program (ERSAP) in Egypt. These changes aimed at improving the effects of monetary policy shocks on the supply of bank loans. Firstly, the Central Bank of Egypt (CBE) liberalized interest rates and the exchange rate from 1991. Secondly, the government eliminated interest rate and credit ceilings. The banks were given the freedom to determine the interest rate on deposits and loans. Thirdly, the intermediate target of monetary policy was changed from the money supply to interest rates and the operational target of monetary policy was changed from banks' excess reserves to the overnight interest rate from the year 2005. Finally, the government privatized fourteen banks in 1996 to increase competition and efficiency among the banks (Omran $2007)^{3}$.

Liberalization of interest rates, targeting interest rates and privatization of banks were all envisaged to enhance competition and efficiency in the banking sector in Egypt. Competition and efficiency strengthen the link between monetary policy and macroeconomics variables, and improve the effect of monetary policy on macroeconomics variables, especially loans (Shrestha and Chowdhury 2006). This is because private banks are deemed to be more efficient than public banks. Furthermore, the entrance of foreign banks, which are more efficient than domestic banks, improves efficiency in the banking sector as competition forces the domestic banks to develop themselves (Bonin et al. 2005). In addition, the liberalization of the banking sector inevitably leads to increases in productivity and improves the quality of financial services, financial technology and human capital (Denizer 1999).

The existing studies in Egypt lend no credence to the importance of the bank lending channel. For example, Hassan (2003) studied the effects of monetary policy on private credit using a structural vector auto regression (SVAR) model and found that monetary policy does not have a significant effect on domestic credit. Similarly, Al-Mashat and Billmerier (2008) also studied the effects of monetary policy on bank loans using the VAR model and found the effects to be insignificant. However, the above mentioned studies have three defects because they used aggregate data. Firstly, they treat banks as homogenous, and this leads to biased estimations. Some macro-level studies, such as Romer et al (1990), Ramey (1993), fail to find a significant relationship between monetary policy and loans due to the problems of simultaneity and heterogeneity of banks, which generate biased estimations (Chatelain et al. 2003; Chirinko et al. 1999). The bank lend-

\footnotetext{
${ }^{2}$ Studies by Kashyap and Stein (1995), Abdul Karim et al. (2011) and Kandra (2012) have supported the bank lending channel and the heterogeneity effect of monetary policy.

${ }^{3}$ The Egyptian banking sector consists of the Central Bank and 40 banks. There are 3 public commercial banks, 27 private \& joint venture banks, 7 foreign banks and 3 specialized banks (CBE 2012).
} 
ing channel might be detected in aggregate studies as monetary policy affects loans through changes in bank assets. It is difficult to distinguish between shifts in the loan supply and demand when aggregate data is used (Bernanke 1992). Secondly, these studies placed emphasis on traditional interest rates only and did not encompass the credit view of monetary policy. Thirdly, they do not highlight the importance of bank-specific variables, such as the size of the banks, their liquidity and capital, in investigating the response of loans to monetary policy shocks (Bernanke and Gertler 1995).

This study is interested in identifying the impact of monetary policy on bank loans using disaggregated data and the Generalized Method of Moments (GMM) model to ascertain if the bank lending channel is operative in Egypt. Secondly, it investigates the importance of bank-level variables, namely the banks' size, liquidity and capital, in analyzing the response of loans to monetary policy shocks. Thirdly, it examines the effects of macro level variables, namely output and inflation, on bank loans. Finally, it studies the heterogeneity effect of monetary policy on bank loans, according to the size of the banks.

The research contributes to the existing literature on the bank lending channel of monetary policy in four ways. Firstly, most studies are focused on the advanced countries, while some small studies are carried out on developing countries. The current study would extend the existing literature by studying the bank lending channel in Egypt. Secondly, it improves on the existing studies in Egypt by examining the effects of monetary policy on loans, using disaggregated data and the GMM technique. Thirdly, it improves on existing studies in Egypt by treating banks as heterogeneous. Fourthly, there are no empirical studies investigating the effects of mon- etary policy on bank loans in Egypt, using panel data. Therefore, this research would fill this gap by studying the bank lending channel of monetary policy, using panel data.

Several interesting features emerge from this paper. Firstly, it supports the significant effects of monetary policy on bank loans, using firm-level data. Secondly, it highlights the significance of the banks' size, liquidity and capital in investigating the response of loans to monetary policy shocks. Thirdly, it supports the impact of macro-level variables, namely output and inflation, on banks' loans. Finally, it supports the heterogeneity effect of monetary policy on loans, according to the size of the banks.

The rest of this paper is structured as follows. Section two provides the literature review of the bank lending channel at macro and bank level. Section three includes the theoretical framework. Section four presents the GMM model and description of the variables. The Section five provides the empirical results. Finally, section six offers conclusions and provides some implications.

\section{Literature Review}

Empirical studies have given importance to the bank-lending channel. Some empirical studies used aggregate data and others used firm level data. The studies on the bank lending channel are divided into two groups, namely macro-level and firm-level studies.

\section{Evidence of the Bank Lending Channel: Macro-level Study}

Many studies in the United States support the bank lending channel. For instance, Bernanke and Blinder (1988) used the commodities and credit curve (CC) and liquidity 
and money curve (LM) to investigate the bank lending channel. They assumed that there are three assets, namely money, bonds and loans. Secondly, banks cannot easily replace lost deposits with other funds. Thirdly, loans and bonds are not perfect substitutes. Fourtbly, the central bank influences the supply of loans by changing the reserve levels. They found that the Federal Bank affects reserves, deposits and loans. In another paper, Bernanke and Blinder (1992) found that tight monetary policy reduces deposits and assets and that most of the decrease in assets are from securities rather than loans. This is because banks react to a fall in assets by selling securities in the short term and reducing loans in the long term (Bernanke 1992). Kashyap et al (1992) found that a tight monetary policy reduces the supply of bank loans because it changes the mix of loans and commercial papers, by increasing the percentage of commercial papers toloans. Driscoll (2004) found that monetary policy shocks have significant effects on loans.

However, both Romer et al (1990) and Ramey (1993) argued that the bank lending channel is not important. Romer et al (1990) found that a tight monetary policy does not affect loans. Ramey (1993) also found that the money channel is more significant than the credit channel. These objections by Romer et al (1990) and Ramey (1993) were addressed by Kashyap and Stein (1995) and Bernanke and Gertler (1995). According to Kashyap and Stein (1995), monetary policy does not affect bank loans as external finance could be raised with perfect elasticity. Hence this affects the importance of the bank lending channel. Bernanke and Gertler (1995) argued that the existence of the bank lending channel does not mean that banks are incapable of replacing lost deposits totally. It is sufficient to require that banks do not face elastic demand for their open-market liabilities.

Many studies support the bank lending channel in other countries. Hülsewig et al. (2006) examined the bank lending channel in Germany, using aggregate data and the VAR model. They found that a contraction in monetary policy decreases bank loans. Therefore, they verified the importance of the bank lending channel. In Japan, Hosono (2006) substantiated the existence of the bank lending channel, using aggregate data. In China, Sun et al. (2010) also confirmed the existence of the bank lending channel of monetary policy, using aggregate data. In Chile, Alfaro et al. (2004) supported the importance of the bank lending channel, using macro-level data.

\section{Evidence of the Bank Lending Channel: Bank-Level Study}

Many studies support the bank lending channel in the United States, using firm level data. For instance, Kashyap and Stein (1995) used disaggregated data, for the period from 1976 to 1992 , on loans, securities, deposits and interest rates. They found that there is a difference between the response of small and large banks. A higher interest rate leads to a significant decrease in small banks' loans, but not in large banks' loans. Therefore, small banks are more sensitive to monetary policy shocks than large banks. In another study, Kashyap and Stein (1994) ascertained the importance of the bank lending channel, by using both aggregate and cross-section data. Kandrac (2012) used the GMM model and disaggregated data for the period from 1993 to 2008. He found a negative and significant relationship between interest rates and bank 
loans. Also, monetary policy shocks have a stronger effect on small banks, compared to large banks.

In the European countries, Kashyap and Stein (1997) found that the importance of the bank lending channel varies according to the countries. In the United Kingdom (UK), the banking lending channel is weak, while it is stronger in Italy and Portugal. In other countries, the banking lending channel is of medium importance. Kakes and Sturm (2002) studied the bank lending channel in Germany, using disaggregated data and a vector error-correction model (VECM). They found that small banks hold relatively large amounts of liquid assets and reduce loans after monetary contractions, compared to large banks. On the other hand, large banks hold relatively little liquid assets, compared to small banks and insulate their loans from monetary policy shocks. Favero et al. (1999) also affirmed the importance of the bank lending channel in France, Germany, Italy and Spain. De Bondt (1998) further verified the importance of the bank lending channel in Europe, which he found to be stronger in Germany, Belgium and the Netherlands and not as significant in the United Kingdom.

In the European countries, many studies support the bank lending channel, using the GMM technique. For instance, Ehrmann et al. (2002) studied the bank lending channel in the euro area, using panel data and GMM techniques. They found that the interest rate influences bank loans in the euro area. Huang (2003) also used the GMM model and supported the bank lending channel in the United Kingdom. Gambacorta (2005) supported the bank lending channel in Italy using panel data and the GMM model. He also confirmed the importance of liquidity and capital in the response of loans to monetary policy shocks. Golodniuk (2006) used panel data and the GMM model and found that the higher the capitalization, the less responsive a bank is to monetary policy shocks. Jimborean (2009) used the GMM model and disaggregated data in Central and Eastern Europe countries, over the period from 1998 to 2006 . He found that small banks modify lending more than large banks, after monetary policy shocks. It was evident that monetary policy has a stronger effect on small banks compared to large banks. In Turkey, Akinci et al. (2013) used the GMM technique and panel data, during the period from 1991 to 2007. They found that the bank lending channel was effective.

In Japan, Hosono (2006) examined the bank lending channel and supported the effect of monetary policy on loans. During the banking crisis in the 1990s, expansionary monetary policy played an important role in mitigating the negative effects of the crisis, by providing liquidity to illiquid banks. Ogawa and Kitasaka (2000) analyzed the bank lending channel in Japan, based on panel data set for the period from 1976 to 1995, and the GMM technique. They found that small banks are more sensitive to monetary policy shocks than large banks. In China, Sun et al. (2010) supported the existence of the bank lending channel, using aggregate and disaggregated data and the heterogeneous behavior between banks' loans, in response to monetary policy shocks.

In other counties, many studies support the importance of the bank lending channel. In Malaysia, Abdul Karim et al. (2011) examined the effects of interest rates on bank loans, using disaggregated data and the GMM model. They found that interest rate shocks have a significant influence on bank loans. Moreover, the banks' size, liquidity and capitalization play an important role in influencing the response of loans to monetary policy 
shocks. In Chile, Alfaro et al. (2004) supported the significance of the bank lending channel, using both micro and macro-level data. In Greece, Brissimis et al. (2001) affirmed the significant impact of monetary policy on bank loans. The larger banks and the more liquid banks are able to protect their loans from monetary policy shocks. In Brazil, Auel and De Mendonça (2011) found a significant relationship between interest rates and loans, using the GMM model. In the emerging economies of Asia, Latin America and Central and Eastern Europe, Wu et al. (2011) supported the existence of the bank lending channel, using the GMM model. In Mexico, Mora (2013) found that small banks are more sensitive to monetary policy shocks than large banks.

\section{Bank Lending Channels in Egypt}

In the Egyptian context, the existing studies used aggregate data to investigate the bank lending channel. For instance, Hassan (2003) studied the effect of monetary policy on private credit, using aggregate data and a structural vector auto regression model (SVAR). He found that monetary policy does not have a significant effect on private credit (Hassan 2003). In addition, Al-Mashat and Billmerier (2008) studied the effects of monetary policy on bank loans, using the VAR model and aggregate data. They found that the effect of monetary policy on loans is insignificant (Al-Mashat and Billmeier 2008).

The studies by Hassan (2003) and AlMashat and Billmerier (2008), used aggregate data to study the bank lending channel. However, this paper uses panel data and the GMM model to examine the bank lending channel in Egypt. In addition, this study highlights theimportance of firm level variables, namely the banks' size, liquidity and capital, in in- vestigating the response of loans to monetary policy shocks. It is more suitable to use disaggregated data to examine the bank lending channel than aggregate data. This is because using disaggregated data has some advantages. Firstly, using disaggregated data treats banks as heterogeneous. Secondly, it encompasses both the traditional interest rate and the credit view of monetary policy. Thirdly, it highlights the importance of firm-level variables, such as the size of banks, and their liquidity and capital, in investigating the response of bank loans to monetary policy shocks.

\section{Theoretical Model}

The bank lending channel of monetary policy could be analyzed using a simple model introduced by Bernanke and Blinder (1988) and further developed by Ehrmann et al. (2002). Bernanke and Blinder (1988) assumed that there are three assets: money, bonds and loans, and banks cannot easily replace deposits with other funds. Also that loans and bonds are not perfect substitutes, and that the central bank could affect the loan supply by changing the reserve levels of the banks. The loan demand is a function of the loans' interest rate (i), gross national product (y) and bonds' interest rates (p). Therefore, the equation of loan demand is:

$$
\mathrm{L}_{\mathrm{d}}=\mathrm{a}_{1} \mathrm{p}+\mathrm{a}_{2} \mathrm{y}-\mathrm{a}_{3} \mathrm{i}_{1}
$$

If the balance sheet of the bank contains four elements, which are deposits, reserves, bonds and loans. The next equation shows the balance sheet at the equilibrium point.

Total assets $=$ Total liabilities

Loans + Bonds + Reserves $=$ Deposits

$\mathrm{D}=\mathrm{L}+\mathrm{B}+\mathrm{R}$ 
Suppose that banks tend to maximize loans subject to:

$\mathrm{L}+\mathrm{B}+\mathrm{ER}=\mathrm{D}(1-\mathrm{rd})$

$\mathrm{R}=\mathrm{ER}+\mathrm{RR}$

where $\mathrm{R}=$ Total reserves; $\mathrm{ER}=$ excess reserves, and $R R=$ required reserves.

Loan supply is a function of the loans' interest rate $\left(\mathrm{i}_{l}\right)$, bonds' interest rates $(\mathrm{p})$, deposits (D) and required reserve ratio (d). Therefore, the equation of the loan supply is as follows:

$$
\begin{aligned}
& L^{s}=-b_{1} p+b_{2} D(1-d)+b_{3} i_{1} \\
& \text { or } \quad L s=-b_{1} p+b_{2} D+b_{3} i_{1}
\end{aligned}
$$

If the market is clear, loan demand equals loan supply at the equilibrium point.

$$
\begin{aligned}
& L^{d}=L^{s} \\
& a_{1} p+a_{2} y-a_{3} i=-b_{1} p+b_{2} D+b_{3} i
\end{aligned}
$$

Ehrmann et al (2002) improved on Bernanke and Blinder's (1988) model. They assumed that deposits (D) equal money (M) and depended on a monetary policy variable (interest rates i). Therefore, the equation for deposits and money is as follows:

$\mathrm{M}=\mathrm{D}=-\mathrm{ai}+\chi$

On the assets side, there are loans $(\mathrm{L})$ and securities (S). On the liabilities side, there are deposits (D), capital (C) and non-secured funding (B). When the balance sheet is balanced, total assets equal total liabilities.

$\mathrm{L}+\mathrm{S}=\mathrm{D}+\mathrm{C}+\mathrm{B}$

Ehrmann et al (2002) assumed that loan demand $\left(\mathrm{L}_{\mathrm{i}}^{\mathrm{d}}\right)$ depends on the real gross domestic product (y), price levels (p) and loans' interest rates $\left(i_{l}\right)$. The relationship between price and loan demand is positive. The correlation between output and loan demand is positive. However, the association between the interest rates of loans and loan demand is negative. Therefore, the loan demand function is as follows:

$$
\mathrm{L}_{\mathrm{i}}^{\mathrm{d}}=\mathrm{a}_{1} \mathrm{y}+\mathrm{a}_{2} \mathrm{p}-\mathrm{a}_{3} \mathrm{i}
$$

Loan supply $\left(\mathrm{L}_{\mathrm{i}}^{\mathrm{s}}\right)$ is a function of the deposits (D), loans' interest rates (and a monetary policy variable (interest rates i). The relationship between deposits and loan supply is positive. The correlation between loans' interest rates and loan supply is positive. However, the association between the interest rate and loan supply is negative. Therefore, the loan supply function is as follows:

$$
L_{i}^{s}=\mu_{i} D_{i}+a_{4} i_{1}-a_{5} i_{1}
$$

They assumed that the coefficient of deposits $\left(\mu_{\mathrm{i}}\right)$ is a function of bank characteristics. The lower the coefficient of deposits, the higher the bank characteristics $\left(\chi_{i}\right)$, which include banks' size, liquidity and capital.

$\mu_{\mathrm{i}}=\mu_{0}-\mu_{1} \chi_{\mathrm{i}}$

In the clearing market, loan demand equals loan supply.

$\mathrm{L}_{\mathrm{i}}^{\mathrm{d}}=\mathrm{L}_{\mathrm{i}}^{\mathrm{s}}$

$a_{1} y+a_{2} p-a_{3} i_{1}=\mu_{i} D_{i}+a_{4} i_{1}-a_{5} i$

The equation of profit is as follows:

$\pi=\mathrm{Li}_{1}+\mathrm{Si}_{\mathrm{s}}-\mathrm{Bi}_{\mathrm{b}}-\psi$

After profit maximization, the equation of loan is as follows:

$$
\begin{aligned}
& \mathrm{L}_{\mathrm{it}}=\mathrm{ay}_{\mathrm{t}}+\mathrm{b} \inf _{\mathrm{t}}-\mathrm{c}_{1} \mathrm{i}_{\mathrm{t}}+\mathrm{c}_{2} \mathrm{i}_{\mathrm{t}} \chi_{\mathrm{it}}+ \\
& \mathrm{d} \chi_{\text {it }}+\text { const. }
\end{aligned}
$$

where: $c_{1}$ represents the coefficient of monetary policy, $c_{2}$ represents the coefficient of monetary policy and bank characteristics and 
$\chi_{\mathrm{i}}$ represents bank characteristics [total assets (A), liquidity (Lq) and capital (C)]. The equation of the nominal interest rate shows that nominal the interest rate (i) equals the real interest rate plus inflation.

$\mathrm{i}=\mathrm{r}+\mathrm{inf}$

Therefore, the equation of the real interest rate could be written as follows:

$$
\mathrm{r}=\mathrm{i}-\inf \text {, or }-\mathrm{r}=\inf -\mathrm{i}
$$

From Equation 6 and Equation 7, the equation of loans could be written as follows:

$$
\mathrm{L}_{\mathrm{i}, \mathrm{t}}=\mathrm{ay}_{\mathrm{t}}-\mathrm{c}_{\mathrm{r}} \mathrm{r}_{\mathrm{t}}+\mathrm{c}_{2} \mathrm{i}_{\mathrm{t}} \chi_{\mathrm{i}, \mathrm{t}}+\mathrm{d} \chi_{\mathrm{i}, \mathrm{t}}+\text { const....... }
$$

The bank characteristics $\left(\chi_{\mathrm{it}}\right)$ are determined by three elements: the size of the banks $\left(\mathrm{S}_{\mathrm{it}}\right)$, their liquidity $\left(\mathrm{Lq}_{\mathrm{it}}\right)$ and capitalization (Cap). The banks' size is measured by total $\operatorname{assets}\left(\mathrm{A}_{\mathrm{it}}\right)$. The liquidity $\left(\mathrm{Lq}_{\mathrm{it}}\right)$ is measured by the ratio of liquidity (cash, lending and securities) to total assets $\left(A_{i t}\right)$. Capitalization is defined as the ratio of capital and reserves $\left(C_{i}\right)$ to total assets $\left(A_{i i}\right)$. Most of the empirical studies support the importance of the banks' size, liquidity and capital in investigating the response of loans to monetary policy shocks. Banks with a small size, less liquidity and less capital are more responsive to monetary policy shocks than large banks. By substituting bank characteristics $\left(\chi_{\mathrm{it}}\right)$ in Equation 6 with total assets $\left(\mathrm{S}_{\mathrm{it}}\right)$, liquidity $\left(\mathrm{Lq}_{\mathrm{i}}\right)$ and capitalization $\left(\mathrm{Cap}_{\mathrm{it}}\right)$, the new equation of loans could be written as follows:

$$
\begin{aligned}
\mathrm{L}_{\mathrm{it}}= & \theta \mathrm{L}_{\mathrm{it}-1}+\mathrm{aY} \mathrm{Y}_{\mathrm{t}}+\mathrm{binf}_{\mathrm{t}}-\mathrm{c}_{1} \mathrm{i}_{\mathrm{t}}+\mathrm{c}_{2} \mathrm{i}_{\mathrm{t}} \mathrm{A}_{\mathrm{it}}+ \\
& \mathrm{c}_{3} \mathrm{i}_{\mathrm{t}} \mathrm{Lq}_{\mathrm{it}}+\mathrm{c}_{4} \mathrm{i}_{\mathrm{t}} \operatorname{Cap}_{\mathrm{it}}+\mathrm{d}_{1} \mathrm{~A}_{\mathrm{it}}+ \\
& \mathrm{d}_{2} \mathrm{Lq}_{\mathrm{it}}+\mathrm{d}_{3} \operatorname{Cap}_{\mathrm{it}}+\lambda_{\mathrm{it}}+\mu_{\mathrm{it}}+v_{\mathrm{it}} \ldots \ldots . .
\end{aligned}
$$

In Equation 9, $\left(\mathrm{L}_{\mathrm{it}-1}\right)$ is a predetermined variable. The lagged dependent variable $\left(\mathrm{L}_{\mathrm{it}-1}\right)$ is added to Equation 9 for two reasons. Firstly, lagged loans affect current loans. If the bank had increased its loans in the past, the ability of the bank to expand current loans would be reduced. Secondly, the lagged loans are added to change the equation to a dynamic version. This is because the GMM model deals with dynamic dependant variables. From Equation 7 and Equation 9, the equation of loans could be written as follows:

$$
\begin{aligned}
\mathrm{L}_{\mathrm{it}}= & \theta \mathrm{L}_{\mathrm{it}-1}+\mathrm{aY} \mathrm{Y}_{\mathrm{t}}+\mathrm{c}_{\mathrm{r}} \mathrm{r}_{\mathrm{t}}+\mathrm{c}_{2} \mathrm{i}_{\mathrm{t}} \mathrm{A}_{\mathrm{it}}+\mathrm{c}_{3} \mathrm{i}_{\mathrm{t}} \mathrm{Lq}_{\mathrm{it}}+ \\
& \mathrm{c}_{4} \mathrm{i}_{\mathrm{t}} \operatorname{Cap}_{\mathrm{it}}+\mathrm{d}_{1} \mathrm{~A}_{\mathrm{it}}+\mathrm{d}_{2} \mathrm{Lq}_{\mathrm{it}}+\mathrm{d}_{3} \operatorname{Cap}_{\mathrm{it}}+ \\
& \lambda_{\mathrm{it}}+\mu_{\mathrm{it}}+\mathrm{v}_{\mathrm{it}} \ldots \ldots \ldots \ldots \ldots \ldots \ldots \ldots \ldots \ldots \ldots \ldots \ldots \ldots \ldots \ldots \ldots \ldots \ldots \ldots \ldots \ldots \ldots \ldots \ldots \ldots
\end{aligned}
$$

In loan Equation (9 or 10), the bank lending channel explains the relationship between monetary policy and bank loans, using the traditional interest rate and external finance premium. The traditional interest rate is represented by the interest rate. The external finance premium is represented by the banks' size $\left(\mathrm{S}_{\mathrm{it}}\right)$, liquidity $\left(\mathrm{Lq}_{\mathrm{it}}\right)$ and capitalization $\left(\mathrm{Cap}_{\mathrm{iit}}\right)$. The interaction between the traditional interest rate and external finance premium is represented by the interaction between the interest rate and the banks' size, liquidity and capitalization. Therefore, the bank lending channel is represented by three channels at the firm-level: the interest rate, bank characteristics (banks' size, liquidity and capitalization) and the interaction between them. As a result, using bank-level data is more suitable than using macro-level data in studying the bank lending channel of monetary policy because it captures these three channels.

Total assets, liquidity and capital are endogenous variables because they are determined inside the model. Output, inflation and interest rates are exogenous variables because they are determined outside the model. For instance, the interest rate represents a mone- 
Table 1. Dependent and Independent Variables

\begin{tabular}{lccc}
\hline & \multicolumn{3}{c}{ Independent Variables } \\
\cline { 2 - 4 } $\begin{array}{c}\text { Dependent } \\
\text { Variable }\end{array}$ & $\begin{array}{c}\text { Predetermine } \\
\text { Variable }\end{array}$ & $\begin{array}{c}\text { Endogenous } \\
\text { Variables }\end{array}$ & $\begin{array}{c}\text { Exogenous } \\
\text { Variables }\end{array}$ \\
\hline Loans $\mathrm{L}_{\mathrm{it}}$ & $\mathrm{L}_{\mathrm{it}-1}$ & $\begin{array}{c}\text { Size of banks }\left(\mathrm{S}_{\mathrm{it}}\right), \\
\text { liquidity }\left(\mathrm{Lq}_{\mathrm{it}}\right) \text { and } \\
\text { capitalization }\left(\mathrm{Cap}_{\mathrm{i}}\right) .\end{array}$ & $\begin{array}{c}\text { Output }(\mathrm{Y}) \text {, inflation }\left(\mathrm{inf}_{\mathrm{t}}\right), \\
\text { and interest rate }\left(\mathrm{i}_{\mathrm{t}}\right)\end{array}$ \\
\hline
\end{tabular}

tary policy variable that is determined by the monetary authorities (Central Bank and Ministry of Finance). Table 1 shows dependent, predetermined, endogenous and exogenous variables. Output (y) and inflation (inf) have a positive relationship with loans (L). For instance, an increase in output leads to higher employment, income, consumption, investment and profit. A rise in consumption and investment boosts loan demand and increases total loans. The correlation between interest rates (i), as a monetary policy variable, and loans is negative. The association between total assets $\left(\mathrm{A}_{\mathrm{it}}\right)$, liquidity $\left(\mathrm{Lq}_{\mathrm{i}}\right)$, capital $\left(\mathrm{C}_{\mathrm{it}}\right)$ and loans is positive. Output, total assets, liquidity and capital are used in the log form, whereas, inflation and interest rates are used in the percentage form.

The independent variables consist of macro and bank specific variables. The macro level variables (time series variables) are output, inflation, and interest rates, and the firm level variables are the size of the banks, and their liquidity and capital. The macro level variables are included in the equation because changes in these variables affect loans according to the standard bank loan model. Thus, the macro economics variables are expected to affect the individual banks' loan supply.
For example, when the central bank changes the interest rate, the banks will response by adjusting their loan supply. However, small banks are more sensitive to monetary policy shocks than large banks, because of asymmetric information, agency cost and the banks' financial position. Many previous studies have considered both macro and firm level variables in modeling the determinants of the bank loan supply, for example Ehrmann et al. (2002), Hosono (2006) and Abdul Karim et al. (2011). These studies believed that the macroeconomic environment and bank specific variables are important factors in influencing the behaviour of the bank loan supply.

\section{Methods}

This research studies the effect of interest rates on bank loans in Egypt, using the GMM model and unbalanced panel data. The data set consists of 32 commercial banks for the period from 1998 to 2011, obtained from bank scope, the International Monetary Fund and the Central Bank of Egypt ${ }^{4}$. There are several reasons for the selection of the commercial banks in examining how relevant is the bank lending channel of monetary policy

${ }^{4}$ In 2005, there were 57banks in Egypt, which were then reduced to 41 banks in 2008 and to 39 banks in 2010 and 2011. In 2012, there were 40 banks that could be categorized into four groups; 3 public commercial banks, 27 private \& joint venture banks, 7 foreign banks and 3 specialized banks. 
in Egypt. First, in Egypt, commercial banks play a vital role as financial intermediaries as compared with others financial intermediaries. For example, the size of the loans and deposits of commercial banks is relatively larger than those of other financial intermediaries. Commercial banks represent 68 percent of all the banks and the biggest five banks in Egypt are commercial banks. Therefore, it is expected that the loans of the commercial banks will respond immediately, following any monetary policy changes. Second, the commercial banks can also create or destroy the money in the market by changing their asset and liabilities. For example, during a monetary contraction (an increase in interest rates), the commercial banks will downsize their loan activities (assets), resulting in less money creation (through deposits) in the market.

\section{GMM Model}

The Generalized Method of Moments (GMM) was introduced by Arellano and Bond (1991), Arellano and Bover (1995) and Blundell and Bond (1998). The GMM model is consistent within a specific situation characterized by a small time period $(\mathrm{T})$, large individuals $(\mathrm{N})$, a linear relationship between variables, a dynamic single dependant variable, independent variables that are not strictly exogenous, a fixed individual effect and no autocorrelation and heteroscedasticity within individuals. Furthermore, the GMM accommodates unbalanced panels data and multiple endogenous variables as well as avoiding the dynamic panel bias (Roodman 2006, 2009).

There are four reasons for using the GMM technique in studying the bank lending channel of monetary policy in Egypt. Firstly, the GMM technique is a better method for solving the endogeneity problem of the explanatory variables, in terms of the correlation between the lagged dependent variable $\left(\mathrm{L}_{\mathrm{i}, \mathrm{-1}}\right)$ and the fixed effect $\left(\mu_{\mathrm{i}}\right)$. Secondly, the GMM technique has the advantage of addressing the Nickell (1981) bias, which results from the relationship between the fixed effect and the independent variables, in a set of panel data that has a small number of time periods and a large number of individuals. Thirdly, the GMM technique is a suitable method for analyzing the panel data of the bank lending channel. Finally, this technique also can investigate the relationship between the monetary policy variable (interest rates), the bank characteristics variables (assets, liquidity and capital), and the interaction between monetary policy and bank characteristics, and the banks' loan supply.

Three assumptions are related to the explanatory variables in the GMM model. Firstly, the explanatory variables could be a predetermined variable that is related to a past error term. Secondly, the explanatory variables could be endogenous variables that are related to past and present error terms. Thirdly, the explanatory variables could be exogenous variables that are not correlated with past, present or future error terms (Karim et al. 2012).

In Equation 10, loans $\left(\mathrm{L}_{\mathrm{i}, \mathrm{t}}\right)$ are a function of the lagged loans $\left(\mathrm{L}_{\mathrm{i}, \mathrm{t}-\mathrm{1}}\right)$, output $(\mathrm{y})$, inflation (inf), interest rate (i $i_{t}$, bank characteristics $\left(\mathrm{c}_{\mathrm{i}, \mathrm{t}}\right)$ and the interaction between the interest rate and bank characteristics $\left(\mathrm{ic}_{\mathrm{i}, \mathrm{t}}\right) . \mathrm{L}_{\mathrm{i}, \mathrm{t}}$; is the dependent variable, and $\mathrm{L}_{\mathrm{i}, \mathrm{t}-1}$ : is a predetermined variable or lagged dependent variable. Output, inflation and interest rates (y, inf, i) are exogenous variables and bank characteristics $\left(\mathrm{c}_{\mathrm{i}, \mathrm{t}}\right)$ are endogenous variables.

$$
\begin{aligned}
\mathrm{L}_{\mathrm{i}, \mathrm{t}}= & \theta \mathrm{L}_{\mathrm{i}, \mathrm{t}-1}+\mathrm{ay}_{\mathrm{t}}+\mathrm{binf}_{\mathrm{t}}-\mathrm{c}_{1} \mathrm{i}_{\mathrm{t}}+\mathrm{c}_{2} \mathrm{i}_{\mathrm{t}} \chi_{\mathrm{i}, \mathrm{t}}+ \\
& \mathrm{d} \chi_{\mathrm{i}, \mathrm{t}}+\mu_{\mathrm{it}}+\mathrm{v}_{\mathrm{i}, \mathrm{t}} \ldots \ldots \ldots \ldots \ldots \ldots \ldots \ldots \ldots \ldots \ldots \ldots \ldots \ldots \ldots \ldots \ldots \ldots \ldots \ldots
\end{aligned}
$$




$$
\begin{aligned}
& \in_{\mathrm{it}}=\mu_{\mathrm{i}, \mathrm{t}}+v_{\mathrm{i}, \mathrm{t}} \\
& \mathrm{E}\left(\mu_{\mathrm{i}, \mathrm{t}}\right)=\mathrm{E}\left(v_{\mathrm{i}, \mathrm{t}}\right)=\mathrm{E}\left(\mu_{\mathrm{i}} v_{\mathrm{i}, \mathrm{t}}\right)=0
\end{aligned}
$$

In Equation 10, the disturbance term $\left(\epsilon_{\mathrm{it}}\right)$ has two components: a fixed effect $\left(\mu_{\mathrm{it}}\right)$ and idiosyncratic shocks $\left(v_{i t}\right)$. One problem in applying OLS is the correlation between the lagged dependent variable $\left(\mathrm{L}_{\mathrm{i}-1}\right)$ and the fixed effect $\left(\mu_{\mathrm{i}}\right)$. The GMM solves this problem by using the first difference. The first difference transformation (difference GMM) is used to remove the fixed effect $\left(\mu_{\mathrm{i})}\right)$ from the Equation 10. The transformed equation is as follows:

$$
\begin{aligned}
\Delta \mathrm{L}_{\mathrm{i}, \mathrm{t}}= & \theta \Delta \mathrm{L}_{\mathrm{i}, \mathrm{t}-1}+\mathrm{a} \Delta \mathrm{y}_{\mathrm{t}}+\mathrm{b} \Delta \inf _{\mathrm{t}}-\mathrm{c}_{1} \Delta \mathrm{i}_{\mathrm{t}}+ \\
& \mathrm{c}_{2} \Delta \mathrm{i}_{\mathrm{t}} \Delta \chi_{\mathrm{i}, \mathrm{t}}+\mathrm{d} \Delta \chi_{\mathrm{i}, \mathrm{t}}+\Delta \mathrm{v}_{\mathrm{i}, \mathrm{t}}
\end{aligned}
$$

where: $\Delta \mathrm{L}_{\mathrm{i}, \mathrm{t}-1}=\mathrm{L}_{\mathrm{i}, \mathrm{t}-1}-\mathrm{L}_{\mathrm{i}, \mathrm{t}-2}$

$$
\Delta v_{i, t}=v_{i, t}-v_{i, t-1}
$$

Although this method removes the fixed effect $\left(\mu_{\mathrm{it}}\right)$ from the loans' equation, there is a correlation between the lagged loans $\left(\Delta \mathrm{L}_{\mathrm{i}, \mathrm{t}}\right.$ $\left.{ }_{1}\right)$ and idiosyncratic shocks $\left(\Delta v_{i, t}\right)$. Therefore, the system GMM model that includes lagged levels and difference variables was used to address this problem.

According to Blundell and Bond (1998), the lagged levels are weak instruments for transforming the equation. Therefore, they developed a new approach that combines the lagged levels and differences, known as the system GMM model (Roodman 2006). Arellano and Bover (1995) and Blundell and Bond (1998) used the regression in difference and level together to reduce defects of regression in difference, which are biased and imprecise. The instruments of regression in level are the lagged differences and the instruments of regression in difference are the lagged levels (Beck and Levine 2004). In the system GMM, both lagged levels and differences are used as instruments for the regression in difference and level, respectively.

The current study uses the system GMM model which is better than the difference GMM because the system GMM combines levels and differences. In addition, this study uses the one-step and two-step system GMM. As mentioned by Bond (2002), the results of the one-step GMM are better than the twostep GMM when standard errors are very small. However, Windmeijer (2005) argued that the two-step GMM is better than the one-step GMM in determining coefficients with low bias and standard error. This is because the two-step GMM uses finite sample corrected standard errors (Abdul Karim et al. 2011; Roodman 2009; Windmeijer 2006). The system GMM generates many instruments that over-fit the endogenous variables and weaken the Hansen Test. This problem is called instrument proliferation. This study uses two methods to decrease the number of instruments. The first method is using a certain lag of instruments instead of all the lags. The second method is combining instruments into smaller sets by collapsing the block of instruments (Abdul Karim et al. 2011; Roodman 2009).

\section{Variables}

The variables are the net loans, total assets, liquidity, capital, output, inflation and interest rate. Loans are a dependent variable and the other variables are independent variables. The macroeconomics variables are output, inflation and interest rate. They are obtained from the International Monetary Fund (IFS) and the Central Bank of Egypt (CBE). The real gross domestic product (GDP) was selected as a proxy for output. The interbank 
interest rate was selected as a proxy for monetary policy variable and the percentage change in consumer price index (CPI) was selected as a proxy for inflation. The firm variables are the net loans, total assets, liquidity and capital. Total assets represent the size of the banks and securities represent liquidity as the quantum of liquidity is not available in Egyptian banks. Equities represent the value of capital because its quantum is also not available in Egyptian banks. The firm-level data is collected from the bank scope for the period from 1998 to 2011. Output, net loans, total assets, liquidity and securities are used in $\log$ form. Inflation and interest rates are used in percentage form.

\section{The Results}

\section{Full Sample}

Tables (2 and 3) show the relationship between loans, as the dependent variable, and the independent variables, namely the lagged loans, interest rate, output (GDP), inflation as well as the interaction between the interest rate and bank characteristics (total assets, equities and securities). The number of instruments is less than the number of groups. Arellano-Bond AR (1) test is less than 10 percent. Arellano-Bond AR (2) and Hansen tests are higher than 10 percent in one-step and two-step estimations, which implies that

Table 2. System GMM Estimation (Whole Sample)

\begin{tabular}{|c|c|c|c|c|c|c|}
\hline \multirow[b]{2}{*}{ Variables } & \multicolumn{3}{|c|}{ Two-step Estimation } & \multicolumn{3}{|c|}{ One-step Estimation } \\
\hline & Coef. & Std. Err. & $P$ value & Coef. & Std. Err. & $P$ value \\
\hline \multicolumn{7}{|l|}{$\overline{\text { loans }}$} \\
\hline L1. & 0.43 & 0.109 & $0 * * *$ & 0.377 & 0.113 & $0.001 * * *$ \\
\hline Interest rate & -0.091 & 0.039 & $0.020 * *$ & -0.095 & 0.037 & $0.01 * * *$ \\
\hline Assets $\mathrm{x}$ interest & 0.42 & 0.228 & $0.064 *$ & 0.209 & 0.207 & 0.312 \\
\hline Equities $\mathrm{x}$ interest & 0.13 & 0.065 & $0.051 *$ & 0.185 & 0.059 & $0.002 * * *$ \\
\hline Securities $\mathrm{x}$ interest & -0.04 & 0.097 & 0.666 & 0.007 & 0.099 & 0.945 \\
\hline GDP & 0.48 & 0.217 & $0.027 * *$ & 0.576 & 0.209 & $0.006 * * *$ \\
\hline Inflation & 0.03 & 0.011 & $0.003 * * *$ & 0.037 & 0.010 & $0 * * *$ \\
\hline Cons. & -4.709 & 2.914 & 0.106 & -0.095 & 0.037 & $0.059 *$ \\
\hline N. of instruments & 29 & & & 29 & & \\
\hline N. of observations & 207 & & & 207 & & \\
\hline Number of groups & 32 & & & 32 & & \\
\hline Arellano-Bond AR(1) & 0.034 & & & 0.009 & & \\
\hline Arellano-Bond AR(2) & 0.715 & & & 0.72 & & \\
\hline Hansen test & 0.266 & & & 0.0226 & & \\
\hline Difference & 0.252 & & & 0.252 & & \\
\hline
\end{tabular}

Notes: $\left.{ }^{(* *}\right)$ means a significant effect at $(1 \%),\left({ }^{* *}\right)$ means a significant effect at $(5 \%)$ and $\left({ }^{*}\right)$ means a significant effect at $(10 \%)$. 
these tests are statistically insignificant in the model and there is no autocorrelation between residuals.

Table 2 shows the estimation results of the determinants of the banks' loans using one-step and two-step system GMM estimation. Macroeconomic variables, gross domestic product (GDP) and inflation (inf) have a positive relationship with loans in the onestep and two-step system GMM estimations. However, the correlation between interest rates (i) and loans is negative in the one-step and two-step estimations. However, the interaction between the interest rate and total assets has a positive association with loans in the one-step and two-step estimations. Also, the interaction between interest rates and equities has a positive relationship with loans in the said estimations. On the contrary, the interaction between the interest rate and securities shows a negative correlation with loans in the two-step estimation but is positive in the one-step estimation.

The relationship between inflation and loans is significant at one percent significance level in the one-step and two-step system estimations. The correlation between GDP and loans is significant at five percent significance level in the two-step and one percent in the one-step estimations. The correlation between interest rates and loans is significant at five percent significance level in the two-step and one percent in the one-step estimations. Meanwhile, the interaction between total assets and interest rates is significant at ten percent in the two-step, but insignificant in the one-step estimations. The interaction between interest rates and equities is significant at ten percent in the twostep and one percent in one-step estimations.

\section{Table 3. Difference GMM Estimation (Whole Sample)}

\begin{tabular}{|c|c|c|c|c|c|c|c|}
\hline \multirow[b]{2}{*}{ Variables } & \multicolumn{3}{|c|}{ Two-step Estimation } & \multicolumn{4}{|c|}{ One-step Estimation } \\
\hline & Coef. & Std. Err. & P value & Coef. & Std. Err. & $\mathbf{P}$ valu & \\
\hline \multicolumn{8}{|l|}{ loans } \\
\hline L1. & 0.590 & 0.085 & $0 * * *$ & 0.582 & 0.095 & $0 *$ & $k * *$ \\
\hline Interest rate & -0.110 & 0.045 & $0.015 * *$ & -0.102 & 0.043 & $0.018 *$ & k* \\
\hline Assets $\mathrm{x}$ interest & 0.744 & 0.382 & $0.052 *$ & 0.700 & 0.267 & $0.009 *$ & $k * *$ \\
\hline Equities $\mathrm{x}$ interest & -0.087 & 0.117 & 0.456 & -0.069 & 0.104 & 0.503 & \\
\hline Securities $\mathrm{x}$ interest & -0.203 & 0.067 & $0.002 * * *$ & -0.189 & 0.083 & $0.022 *$ & k* \\
\hline GDP & 0.553 & 0.227 & $0.015 * *$ & 0.409 & 0.179 & $0.023 *$ & k* \\
\hline Inflation & 0.042 & 0.016 & $0.008 * * *$ & 0.032 & 0.013 & $0.012 *$ & k* \\
\hline N. of instruments & 29 & & 29 & & & & \\
\hline N. of observations & 175 & & 175 & & & & \\
\hline Number of groups & 32 & & 32 & & & & \\
\hline Arellano-Bond AR(1) & 0.034 & & 0.009 & & & & \\
\hline Arellano-Bond AR(2) & 0.715 & & 724 & & & & \\
\hline Hansen test & 0.266 & & 0.266 & & & & \\
\hline Difference & 0.252 & & 0.252 & & & & \\
\hline
\end{tabular}

Notes: $\left(^{* *}\right)$ means a significant effect at $(1 \%),(* *)$ means a significant effect at $(5 \%)$ and $(*)$ means a significant effect at $(10 \%)$. 
However, the interaction between the interest rate and securities is insignificant in the one-step and two-step estimations. For example, 1 percent increase in the interest rate reduces loans by negative 0.091 units in the two-step and 0.095 units in the one-step estimations. When gross domestic product rises by one unit, loans go up by 0.48 units in the two-step and 0.576 units in the one-step estimations.

Table 3 shows the estimation results of the determinants of the banks' loans using the one-step and two-step difference GMM estimation. The relationship between inflation and loans is significant at one and five percent significance level in the two-step and one-step estimations. The correlation between GDP and loans is significant at five percent significance level in the two-step and one-step estimations. The correlation between interest rates and loans is significant at five percent significance level in the twostep and one percent in the one-step estimations. Meanwhile, the interaction between total assets and interest rates is significant at ten percent in the two-step and one percent in the one-step estimations. However, the interaction between the interest rate and equities is insignificant in the two-step and onestep estimations. The interaction between the interest rate and securities is significant at one and five percent in the one-step and two-step estimations. For example, 1 percent increase in the interest rate reduces loans by negative (0.110) units in the two-step and (0.102) units in the one-step estimations.

It is therefore evident that the interest rate has a significant effect on bank loans. The macroeconomic variables, namely output and inflation, also have a significant effect on loans. Further, the interaction between the interest rate and total assets has a significant impact on loans. Although the in- teraction between the interest rate and equities is significant, the interaction between the interest rate and securities does not have an important effect on loans in the system GMM model.

\section{Subsample}

Firstly subsample includes the smallest 27 commercial banks in Egypt based on total assets, securities and equities, the largest 5 banks are excluded from this sample. Firstly, the average of their total assets, securities and equities are estimated for all banks. Secondly, the total average for all the banks is determined. Thirdly, the smallest 27 banks are selected and the results are explained in Table 4, whereas, the largest 27 banks results are explained in Table 5 .

Table 4 shows the one-step and twostep system GMM estimations of the smallest banks in Egypt based on total assets, securities and equities. The correlation between inflation and bank loans is significant at one percent significance level in the one-step and two-step estimations. The relationship between interest rates and loans is significant at one percent in the two-step and five percent in the one-step estimations. The relationship between output and loans is significant at five percent in the two-step and one percent in the one-step estimations. The interaction between the interest rate and total assets is significant at one percent significance level in the two-step and one-step estimations. However, the interaction between the interest rate and equities becomes insignificant in the two-step and one-step estimations, it is significant in Table 2. The interaction between interest rates and securities becomes significant at one percent in the two-step and one-step estimations, it is insignificant in Table 2. In the smallest banks sample, 1 percent increase in the interest rate reduces loans 
Table 4. System GMM Estimation of the Smallest 27 Banks in Egypt

\begin{tabular}{|c|c|c|c|c|c|c|}
\hline \multirow[b]{2}{*}{ Variables } & \multicolumn{3}{|c|}{ Two-step Estimation } & \multicolumn{3}{|c|}{ One-step Estimation } \\
\hline & Coef. & Std. Err. & $P$ value & Coef. & Std. Err. & P value \\
\hline \multicolumn{7}{|l|}{ loans } \\
\hline L1. & 0.577 & 0.086 & $0 * * *$ & 0.491 & 0.112 & $0 * * *$ \\
\hline Interest rate & -0.100 & 0.033 & $0.003 * * *$ & -0.112 & 0.045 & $0.013 * *$ \\
\hline Assets $\mathrm{x}$ interest & 1.063 & 0.181 & $0 * * *$ & 0.970 & 0.213 & $0 * * *$ \\
\hline Equities $\mathrm{x}$ interest & -0.048 & 0.050 & 0.34 & -0.023 & 0.057 & 0.682 \\
\hline Securities $\mathrm{x}$ interest & -0.194 & 0.044 & $0 * * *$ & -0.182 & 0.071 & $0.01 * * *$ \\
\hline GDP & 0.656 & 0.273 & $0.016 * *$ & 0.705 & 0.265 & $0.008 * * *$ \\
\hline inflation & 0.054 & 0.012 & $0 * * *$ & 0.053 & 0.013 & $0 * * *$ \\
\hline CONS & -11.33 & 4.89 & $0.021 * *$ & -10.74 & 4.297 & $0.012 * *$ \\
\hline N. of instruments & 25 & & 35 & & & \\
\hline N. of observations & 171 & & 171 & & & \\
\hline Number of Groups & 21 & & 21 & & & \\
\hline Arellano-Bond & 0.017 & & 0.088 & & & \\
\hline $\operatorname{AR}(1)$ & 0.772 & & 0.549 & & & \\
\hline Arellano-Bond & 0.524 & & 0.524 & & & \\
\hline $\operatorname{AR}(2)$ & 0.557 & & 0.557 & & & \\
\hline \multicolumn{7}{|l|}{ Hansen test } \\
\hline Difference & & & & & & \\
\hline
\end{tabular}

Notes: $\left(^{* *}\right)$ means a significant effect at $(1 \%),\left({ }^{*}\right)$ means a significant effect at $(5 \%)$ and $\left(^{*}\right)$ means a significant effect at $(10 \%)$.

by negative 0.100 and 0.112 units in the twostep and one-step estimations, respectively, they are 0.091 and 0.095 units in the whole sample. It implies that the response of the smallest banks to monetary policy shocks is more effective than the response of other banks. Therefore, the smallest banks are more sensitive to monetary policy shocks than other banks.

Table 5 shows the one-step and twostep estimations of the largest banks in Egypt based on total assets, securities and equities. The relationship between inflation and loans is significant at one percent significance level in the one-step and two-step estimations. The correlation between interest rates and loans is insignificant in the two-step but significant at ten percent significance level in the onestep estimation. The relationship between output and loans is significant at one percent in the two-step and one-step estimations. Meanwhile, the interaction between the interest rate and total assets is insignificant in the two-step and one-step estimations. The interaction between interest rates and equities is significant at one percent in the twostep and one-step estimations. However, the interaction between interest rates and securities is insignificant in the two-step and onestep estimations. In the largest banks sample, 1 percent increase in the interest rate leads to a decrease in loans by negative 0.060 units 
Table 5. System GMM Estimation of the Largest 27 Banks in Egypt

\begin{tabular}{|c|c|c|c|c|c|c|}
\hline \multirow[b]{2}{*}{ Variables } & \multicolumn{3}{|c|}{ Two-step Estimation } & \multicolumn{3}{|c|}{ One-step Estimation } \\
\hline & Coef. & Std. Err. & $P$ value & Coef. & Std. Err. & $P$ value \\
\hline \multicolumn{7}{|l|}{ loans } \\
\hline L1. & 0.642 & 0.163 & $0 * * *$ & 0.539 & 0.056 & $0 * * *$ \\
\hline Interest rate & -0.06 & 0.039 & 0.125 & -0.08 & 0.041 & $0.055 *$ \\
\hline Assets $\mathrm{x}$ interest & 0.036 & 0.307 & 0.907 & 0.207 & 0.214 & 0.334 \\
\hline Equities $\mathrm{x}$ interest & 0.229 & 0.085 & $0.007 * * *$ & 0.173 & 0.056 & $0.002 * * *$ \\
\hline Securities $\mathrm{x}$ interest & -0.109 & 0.114 & 0.337 & -0.117 & 0.078 & 0.133 \\
\hline GDP & 0.565 & 0.203 & $0.005 * * *$ & 0.597 & 0.188 & $0.001 * * *$ \\
\hline inflation & 0.038 & 0.011 & $0.001 * * *$ & 0.037 & 0.012 & $0.001 * * *$ \\
\hline CONS & -5.322 & 2.641 & $0.044 * *$ & -5.651 & 2.147 & $0.009 * * *$ \\
\hline N. of instruments & 25 & & 25 & & & \\
\hline N. of observations & 174 & & 174 & & & \\
\hline Number of Groups & 27 & & 27 & & & \\
\hline Arellano-Bond AR(1) & 0.072 & & 0.024 & & & \\
\hline Arellano-Bond AR(2) & 0.440 & & 0.377 & & & \\
\hline Hansen test & 0.977 & & 0.483 & & & \\
\hline Difference & 0.375 & & 0.202 & & & \\
\hline
\end{tabular}

Notes: $(* *)$ means a significant effect at $(1 \%),(* *)$ means a significant effect at $(5 \%)$ and $(*)$ means a significant effect at (10\%).

and 0.080 units in the two-step and one-step estimations respectively, smaller than the coefficients of the smallest banks. Therefore, the smallest banks are more sensitive to monetary policy shocks than the largest banks.

The existing studies in Egypt, such as Hassan (2003) and Al-Mashat and Billmerier (2008), used aggregate data to study the bank lending channel. They did not support the effectiveness of the bank lending channel or the heterogeneity effect of monetary policy according to the size of the banks. However, this study uses a dynamic panel GMM technique in modeling the determinants of bank loan supply, and found the relevance of the bank lending channel of monetary policy in Egypt. Using bank-level data is more suit- able than using aggregate data, in studying the bank lending channel, because it treats banks as heterogeneous and also can capture these three possible factors that can influence the lending channels of monetary policy, ie the role of interest rates (monetary policy variable), bank-specific variables (banks' size, liquidity and capital), and the interaction between interest rates and bank-specific variables. In addition, this study also supports the heterogeneity of the monetary policy effects on bank loans according to the difference size of the banks, in which the small banks are more sensitive to monetary policy shocks than the large banks. These results are associated with some studies, such as Kashyap and Stein (1995), Abdul Karim et al. (2011) 
and Kandra (2012), who support the bank lending channel and the heterogeneity effect of monetary policy.

\section{Summary and Conclusions}

Firstly examines the effect of monetary policy on bank loans using disaggregated data and the GMM model to ascertain if the bank lending channel is operative in Egypt. Secondly, it investigates the importance of firm level variables, namely total assets, liquidity and capital, and macroeconomic variables, namely output and inflation, in analyzing the response of loans to monetary policy shocks. Finally, it studies the heterogeneity of monetary policy monetary policy based on the size of the banks.

The previous studies in Egypt, such as Hassan (2003) and Al-Mashat and Billmerier (2008), used macro level data and did not support the importance of the bank lending channel. However, this paper supports the significant effect of monetary policy on bank loans. Secondly, it highlights the important effects of the interaction between interest rates and total assets on loans. The interaction between interest rates and capital (equities) is significant, whereas, the interaction between interest rates and liquidity (securi- ties) does not have an important effect on loans. Thirdly, it supports the important impact of output and inflation on bank loans. Finally, it sustains the heterogeneity effect of monetary policy on bank loan according to the size of the banks.

The policy implications from this paper indicate that the monetary authorities should take cognizance of the stability of interest rates in order to stabilize the bank loan supply. By stabilizing the bank loan, the central bank is able to stabilize the aggregate demand components that are investment and consumption, with which it can stabilize price levels and domestic output. Secondly, the relevance of the bank lending channel indicates that the role of commercial banks is very important in transmitting monetary policy shocks to the real sector economy. This implies that the monetary authorities need to consider the microeconomics aspect of bank behavior in formulating their policy. Thirdly, the heterogeneity effect of the bank lending channel indicates that the most affected banks are small banks, which need financial assistance during a monetary contraction. Therefore, the small banks need to plan precisely their assets, liquidity and capital in their loans to the private sector.

\section{References}

Abdul-Karim, Z., W. Azman-Saini, and B. Abdul Karim. 2011. Bank lending channel of monetary policy: Dynamic panel data study of Malaysia. Journal of Asia-Pacific Business 12 (3): 225-243.

Akinci, D. A., R. Matousek, N. Radix, and C. Stewart. 2013. Monetary policy and the banking sector in Turkey. Journal of International Financial Markets, Institutions and Money 27: 269-285.

Al-Mashat, R., and A. Billmeier. 2008. The monetary transmission mechanism in Egypt. Review of Middle East Economics and Finance 4 (3): 2.

Alfaro, R., H. Franken, C. García, and A. Jara. 2004. The bank lending channel in Chile. Banking Market Structure and Monetary Policy: 121-145. 
Auel, M. C., and H. F. De Mendonça. 2011. Macroeconomic relevance of credit channels: Evidence from an emerging economy under inflation targeting. Economic Modelling 28 (3): 965-979.

Beck, T., and R. Levine. 2004. Stock markets, banks, and growth: Panel evidence. Journal of banking and finance 28 (3): 423-442.

Bernanke, B. S. 1990. The federal funds rate and the channels of monetary transnission. Working Paper (3487). National Bureau of Economic Research, Cambridge, Mass., USA.

Bernanke, B. S., and A. S. Blinder. 1988. Credit, money, and aggregate demand. Working Paper (2534). National Bureau of Economic Research. Cambridge, Mass., USA.

Bernanke, B. S., and M. Gertler. 1995. Inside the black box: The credit channel of monetary policy transmission. Working Paper (5146). National Bureau of Economic Research, Cambridge, Mass., USA.

Bonin, J. P., I. Hasan, and P. Wachtel. 2005. Privatization matters: Bank efficiency in transition countries. Journal of banking and Finance 29 (8): 2155-2178.

Brissimis, S., N. Kamberoglou, and G. Simigiannis. 2001. Is there a bank lending channel of monetary policy in Greece? Evidence from bank level data. Working Paper Series. European Central Bank.

Chatelain, J. B., A. Generale, I. Hernando, U. Von Kalckreuth, and P. Vermeulen. 2003. New findings on firm investment and monetary transmission in the Euro area. Oxford Review of Economic Policy 19 (1): $73-83$.

Chirinko, R. S., S. M. Fazzari, and A. P. Meyer. 1999. How responsive is business capital formation to its user cost? An exploration with micro data. Journal of Public Economics 74 (1): 53-80.

De Bondt, G. 1998. Credit channels in Europe: Bank level panel data analyses. Research Memorandum Wo\&E nr 567/9837

Denizer, C. 1999. The effects of financial liberalization and new bank entry on market structure and competition in Turkey. Research Working Papers 1 (1): 1-57.

Driscoll, J. C. 2004. Does bank lending affect output? Evidence from the US States. Journal of Monetary Economics 51 (3): 451-471.

Favero, C. A., F. Giavazzi, and L. Flabbi. 1999. The transmission mechanism of monetary policy in Europe: Evidence from banks' balance sheets. Working Paper (7231) (July). National Bureau of Economic Research, Cambridge, Mass., USA.

Gambacorta, L. 2005. Inside the Bank Lending Channel. European Economic Review 49(7): 1737-1759.

Golodniuk, I. 2006. Evidence on the bank-lending channel in Ukraine. Research in International Business and Finance 20 (2): 180-199.

Hassan, M. 2003. Can Monetary Policy Play an Effective Role in Egypt? Egyptian Center for Economic Studies.

Hosono, K. 2006. The transmission mechanism of monetary policy in Japan: Evidence from banks' balance sheets. Journal of the Japanese And International Economies 20 (3): 380-405.

Huang, Z. 2003. Evidence of a bank lending channel in the Uk. Journal of Banking and Finance 27 (3): 491510.

Hülsewig, O., E. Mayer, T. Wollmershäuser. 2006. Bank loan supply and monetary policy transmission in Germany: An assessment based on matching impulse responses. Journal of Banking and Finance 30(10): 2893-2910. 
Jimborean, R. 2009. The role of banks in the monetary policy transmission in the New EU member states. Economic Systems 33 (4): 360-375.

Kakes, J., and J.-E. Sturm. 2002. Monetary policy and bank lending: Evidence from German banking groups. Journal of Banking and Finance 26 (11): 2077-2092.

Kandrac, J. 2012. Monetary policy and bank lending to small firms. Journal of Macroeconomics 34 (3): 741 749

Karim, Z. A., M. A. Zaidi, B. A. Karim. 2012. Monetary policy, financial constraints and equity return: Panel evidence. Prosiding PERKEM VII 2: 979-992. ISSN: 2231-962X.

Kashyap, A. K., and J. C. Stein. 1994. Monetary Policy and Bank Lending. The University of Chicago Press, Chicago.

Kashyap, A. K., and J. C. Stein. 1995. The impact of monetary policy on bank balance sheets. CarnegieRochester Conference Series on Public Policy 42 (1): 151-195.

Kashyap, A. K., J. Stein. 1997. The role of banks in monetary policy: A survey with implications for the European Monetary Union. Economic Perspectives-Federal Reverse Bank of Chacago 21: 2-18.

Mishkin, F. S. 1996. The channels of monetary transmission: Lessons for monetary policy. Working Paper (5464) (February). National Bureau of Economic Research, Cambridge, Mass., USA.

Mora, N. 2013. The bank lending channel in a partially dollarized economy. Journal of Applied Economics 16 (1): 121-151.

Ogawa, K., and S-I. Kitasaka. 2000. Bank Lending in Japan: Its Determinants and Macroeconomic Implications. Springer.

Omran, M. 2007. Privatization, state ownership, and bank performance in Egypt. World Development 35 (4): 714-733.

Roodman, D. 2006. How to Do Xtabond2: An Introduction to Difference and System GMM in Stata. Wrking Paper 103 (December). Center for Global Development (http://www.cgdev.org/files/ 11619_file_HowtoDoxtabond8_with_foreword.pdf).

Roodman, D. 2009. A note on the theme of too many instruments. Oxford Bulletin of Economics and Statistics 71 (1): 135-158.

Shrestha, M. B., and K. Chowdhury. 2006. Financial liberalization index for Nepal. International Journal of Applied Econometrics and Quantitative Studies 3 (1): 41-54.

Sun, L., J. L. Ford, and D. G. Dickinson. 2010. Bank loans and the effects of monetary policy in China: Var/Vecm approach. China Economic Review 21 (1): 65-97.

Walsh, C. E. 2003. Monetary Theory and Policy. The MIT Press.

Windmeijer, F. 2006. GMM for panel count data models. Discussion Paper No. 06/591

Wu, J., A. C. Luca, and B. N. Jeon. 2011. Foreign bank penetration and the lending channel in emerging economies: Evidence from bank-level panel data. Journal of International Money and Finance 30 (6): 1128-1156. 
